\title{
Did Politicians Use Non-Public Macroeconomic Information in Their Stock Trades? Evidence from the STOCK Act of 2012
}

\author{
Serkan Karadas ${ }^{1}$ (D), Minh Tam Tammy Schlosky ${ }^{2}$ (D) and Joshua Hall ${ }^{3, * \mathbb{D}}$ \\ 1 College of Business and Management, University of Illinois Springfield, Springfield, IL 62703, USA; \\ skara6@uis.edu \\ 2 School of Business, Lincoln Memorial University, Harrogate, TN 37752, USA; \\ Minhtam.Schlosky@LMUnet.edu \\ 3 John Chambers College of Business and Economics, West Virginia University, Morgantown, WV 26506, USA \\ * Correspondence: joshua.hall@mail.wvu.edu
}

check for

updates

Citation: Karadas, Serkan, Minh Tam Tammy Schlosky, and Joshua Hall. 2021. Did Politicians Use

Non-Public Macroeconomic Information in Their Stock Trades? Evidence from the STOCK Act of 2012. Journal of Risk and Financial Management 14: 256. https:// doi.org/10.3390/jrfm14060256

Academic Editor: Vanja Piljak

Received: 18 May 2021

Accepted: 4 June 2021

Published: 8 June 2021

Publisher's Note: MDPI stays neutral with regard to jurisdictional claims in published maps and institutional affiliations.

Copyright: (C) 2021 by the authors. Licensee MDPI, Basel, Switzerland. This article is an open access article distributed under the terms and conditions of the Creative Commons Attribution (CC BY) license (https:// creativecommons.org/licenses/by/ $4.0 /)$.

\begin{abstract}
Existing research shows that members of Congress made informed trades prior to the passage of the STOCK Act of 2012. There is also evidence in the literature to suggest that the STOCK Act was able to deter politicians from trading based on non-public information. However, the question of whether politicians made informed trades at the market level (using non-public macroeconomic information, not just firm-specific information) in the first place and whether they continued to do so even after the passage of the STOCK Act remains unexamined. We analyze 101,191 individual stock transactions covering the 2004-2014 period and find that the STOCK Act adversely affected the ability of politicians' aggregated stock trades to predict the stock market returns. Our results imply that politicians used non-public macroeconomic information prior to the STOCK Act, and this legislation was influential in deterring politicians from using non-public macroeconomic information in their stock trades. Our findings also provide input on the current debate on the need for the STOCK Act 2.0.
\end{abstract}

Keywords: STOCK Act; informed trading; non-public information; politicians

JEL Classification: G12; G14; G18; D72; D73

\section{Introduction}

Are members of Congress informed traders? Do they buy stocks before good news and sell them before bad news? Do they just trade on hot tips or also make trades using information about the direction of the overall economy (i.e., economy-wide information or macroeconomic information)? These questions held the public's attention and were examined in academic research for almost two decades. For example, news reports highlighted cases where members of Congress may have traded stocks based on pandemic (Covid-19)-related private information (Faturechi and Willis 2020; Markay et al. 2020; Severns and O'Donnell 2020) and on information that they received from the officials at the Department of the Treasury and the Federal Reserve (Kindy et al. 2012). Further, one former member of Congress, Representative Christopher Collins, was even sentenced to 2 years in prison for sharing private information with his son about a failed clinical trial conducted by Innate Immunotherapeutics (Merle 2020). ${ }^{1}$

Ziobrowski et al. $(2004,2011)$ provide the first comprehensive empirical studies on the trading decisions of members of Congress. The authors re-construct the portfolios of members of Congress based on their daily stock transactions (during 1993-1998 for the Senate and 1985-2001 for the House) and document that these portfolios outperform the market. Further evidence in the literature reveals that local knowledge (Eggers and Hainmueller 2014), family ties (Karadas 2018), and the congressional committee powers (Hall et al. 2017; Karadas 2019) affect the portfolio performance of trades reported by politicians.

The common theme among the studies on politicians' stock trades is that they are focused on the detection of abnormal returns on politicians' trades, and they do not address 
the question of whether politicians trade exclusively on firm-specific information (i.e., information that pertains to a single firm such as impending government action in favor of the firm in question) or they use broader sets of information such as information on the overall economy (i.e., macroeconomic or economy-wide information). One exception is the study by Karadas et al. (forthcoming) in that the authors present evidence that politicians use macroeconomic information in their stock trades by showing that an aggregated measure of politicians' stock trades predicts future stock market returns.

To address the concerns that members of Congress could be personally profiting by trading stocks using their unique and powerful positions in the government, Congress passed the Stop Trading on Congressional Knowledge (STOCK) Act in 2012. The public sentiment, anecdotal evidence (e.g., Schweizer 2011; Kroft 2011), and academic research played a role in this legislative outcome. For example, in his testimony to the Subcommittee on Oversight and Investigations of the Committee on Financial Services, Ziobrowski (2009) stated that

With respect to H.R. 682, I am generally supportive of including Members of Congress and their staffs under the insider trading statues. In my opinion, it will likely reduce trading on confidential information. However, it is naive to assume that the practice will be totally eliminated. After all, corporate insiders are still able to earn significant abnormal returns, despite being bound by such laws for many years.

The preceding quote not only provides support for legislating the trading practices of politicians, but it also makes a prediction about the effect of potential legislation on the way that politicians trade stocks. There are now studies that examine whether the STOCK Act had any effect on politicians' trading outcomes. For example, Karadas (2019) finds that the abnormal returns on politicians' trades disappear after the passage of the STOCK Act. In a more recent examination, Belmont et al. (2020) find that post-STOCK Act performance of Senators' trades is mostly mediocre. These studies add significant value to the literature, however they do not address whether members of Congress are still informed at the aggregate level (i.e., possess non-public macroeconomic information) after the passage of the STOCK Act. In other words, we do not know the effect of the STOCK Act on the ability of the politicians' aggregated trades to predict the stock market returns. Our study attempts to address this gap in the literature by examining transactions that politicians made before the passage of the STOCK Act (76,182 transactions) and those that politicians made before and after the passage of the STOCK Act (101,191 transactions). We find that the STOCK Act adversely affected the use of private information by politicians at the aggregate level such that the results reported by Karadas et al. (forthcoming) significantly deteriorates after adding the post-STOCK Act transactions to the sample.

Revealing the effect of the STOCK Act helps us assess the source of predictive ability reported by Karadas et al. (forthcoming). The possibility exists that similar to sell-side analysts (Howe et al. 2009; Karadas and Papakroni 2019), politicians could possess superior skills to interpret the macroeconomic developments in the economy and to extract information from publicly available data. For example, a reported increase in the growth rate of gross domestic product (GDP) in a post-recession period is clearly good news, and ordinary investors are likely to react positively. However, a politician attuned to economic affairs might interpret this piece of news as a temporary improvement based on how he or she thinks the economy will do in the long run. If the predictive ability is due to politicians' superior skills in analyzing publicly available macroeconomic data, the STOCK Act should not cause major changes in their trading process and trading outcomes. The deterioration in the results after adding post-STOCK Act transactions implies that it was not the superior skills, but superior information that drove the results in the Karadas et al. (forthcoming) study in the first place. Overall, our study contributes to the literature by presenting evidence that politicians traded on non-public macroeconomic information prior to the passage of the STOCK Act, and the STOCK Act curbed the use of non-public macroeconomic information in politicians' stock trades. 
The rest of the paper proceeds as follows. We present the legal framework behind the STOCK Act of 2012 and discuss the recent proposals to strengthen the STOCK Act in Section 2. We introduce the data and the empirical model in Section 3 and discuss the results in Section 4. Section 5 presents robustness checks, and Section 6 concludes the paper.

\section{Legal Framework and the STOCK Act of 2012}

The STOCK Act was first introduced by Representatives Brian Baird and Louise M. Slaughter in 2006. Slaughter (2011) argued that passing the STOCK Act would help Congress reverse its extremely low approval rate $(6 \%)$ and would send a strong signal to the public that Congress was interested in addressing their concerns amidst the claims that insider trading laws do not apply to members of Congress (Kroft 2011). Khuzami (2011), the Director of Enforcement at the Securities and Exchange Commission (SEC) at the time, clarified that members of Congress and their staffers are not exempt from insider trading laws whose legal framework is based on Section 10(b) and Rule 10b-5 of the SEC Act of 1934. However, he emphasized that the enforcement of insider trading violations on members of Congress would be challenging due to the lack of a precedent.

Khuzami (2011) argued that "[c]ongressional staff, as employees, owe a duty of trust and confidence to their employer" based on case law. As a result, they are subject to insider trading laws in case they breach this duty by using material nonpublic information gleaned from their work for personal gains. On the other hand, such a duty is ambiguous for members of Congress since " $\mathrm{t}$ ] here does not appear to be any case law that addresses the duty of a Member with respect to trading on the basis of information the Member learns in an official capacity". Therefore, he suggested that any law or amendment to existing laws should clearly state that members of Congress have a duty of trust and confidence that prohibits them from trading on material nonpublic information.

Further, Nagy (2011) firmly stated that insider trading by members of Congress is not legal since "congressional insider trading in securities violates the broad anti-fraud provisions in federal securities law as well as the federal mail and wire fraud statutes". She proposed an amendment to the existing law stating that members of Congress and federal employees owe a duty of trust and confidence when they obtain material nonpublic information from their job. Similar to Khuzami (2011), she argued that there would be no need to pass a new law explicitly banning congressional insider trading. There seems to be a consensus among the enforcement authorities and legal scholars of insider trading laws that the STOCK Act was not necessary to ban politicians from trading on material nonpublic information, and that the same goal could have been accomplished by amending existing laws.

The STOCK Act brought sweeping changes to the way members and staffers of Congress and the Executive Branch reported their financial transactions. Section 3 of the STOCK Act bans members and employees of Congress from using nonpublic information that they obtain in the process of performing their official duties. Section 4 of the STOCK Act explicitly states that members and employees of Congress are subject to insider trading laws. Prior to the STOCK Act, politicians were required to report their transactions by 15 May of each year for the previous calendar year on paper (not online). This process led to a disclosure lag of as long as 17 months. Sections 6 and 8 of the STOCK Act require these transactions to be reported online no later than 30 days after members of Congress are notified of such transactions, but definitely no later than 45 days after they take place. Some politicians state that they do not actually follow which stocks are bought or sold in their accounts, because their brokers handle their investments. By emphasizing the word "notified", these sections of the law ensure that politicians keep track of their transactions, irrespective of who executes them. There are also similar restrictions and regulations for employees and members of the Executive Branch. ${ }^{2}$

The STOCK Act does not take any action against so-called political intelligence firms, except to require an official study examining the extent and influence of their activities. Furthermore, Section 14 of the STOCK Act provides an exception to "widely held invest- 
ment fund (whether such fund is a mutual fund, regulated investment company, pension or deferred compensation plan, or other investment fund), if- (1) (a) the fund is publicly traded; or (b) the assets of the fund are widely diversified; and (2) the reporting individual neither exercises control over nor has the ability to exercise control over the financial interests held by the fund" (US Congress 2012).

The STOCK Act went through changes after it become a law. In 2013, the White House rolled back the provision that stock trades reported by politicians would be searchable and downloadable due to national security reasons (Vardi 2013). Currently, public can access the stock transactions done by members of the Senate and the House on their respective websites. However, some of the transactions were reported via scanned documents (sometimes handwritten) that require extensive efforts to tabulate, and the online disclosures were not as common as they are in the period that we examine (Belmont et al. 2020; Diemer 2014).

There is now momentum to further legislate the trading activity of members of Congress with a new bill H.R.8362 (referred as STOCK Act 2.0). The fact that no politician was found guilty for violating the STOCK Act in the face of anecdotal evidence in the press seems to be contributing to this momentum (Nocera 2020). ${ }^{3}$ The new bill calls for transparency provisions that were actually part of the original STOCK Act but later removed with the 2013 amendment. In particular, the bill asks for a creation of a searchable, sortable and downloaded database where the public can search by "filer name, asset, transaction type, ticker symbol, notification date, amount of transaction, and date of transaction" (US Congress 2020). Another proposal is to restrict the set of securities that politicians can trade to broadly diversified investments such as exchanged traded funds (Augustin et al. 2020). This proposal would require a drastic change from the status quo where members of Congress are allowed to trade individual stocks in any sector, including those they regulate or write bills for.

\section{Data and the Empirical Model}

We obtain politicians' daily stock transactions for the 2004-2014 period from the Center for Responsive Politics (CPR). We hand-match the stocks in the CRP data to the stocks in the Center for Research in Security Prices (CRSP) database. At the end of this process, all the stocks in the sample have a permanent identifier, PERMNO, assigned by CRSP. The sample includes 76,182 transactions in the pre-STOCK era (January 2004 to March 2012) and 101,191 transactions for the full or complete sample period (January 2004 to December 2014).

We adopt the same estimation framework in the Karadas et al. (forthcoming) study. Furthermore, to maintain consistency and comparability with the Karadas et al. (forthcoming) study, we use the same notation and variable names. Karadas et al. (forthcoming) predict the following equation and its condensed versions in their study:

$$
\begin{aligned}
\text { market }_{t}=\beta_{0}+\beta_{1} & \text { PTI }_{t-1}+\alpha_{1} \text { market }_{t-1}+\alpha_{2} \text { market }_{t-3}+\alpha_{3} \text { market }_{t-6} \\
& +\alpha_{4} \text { market }_{t-9}+\alpha_{5} \text { market }_{t-12}+\alpha_{6} \text { market }_{t-24}+\theta_{1} \text { tb3 }_{\text {mrate }}+1 \\
& +\theta_{2} \text { dspread }_{t-1} \\
& +\theta_{3} \text { tspread }_{t-1}+\theta_{4} \text { epratio }_{t-1}+\varepsilon_{t}
\end{aligned}
$$

Using the CRSP data, we calculate market $_{t}$ as the return on the equal-weighted CRSP market index minus 1-month Treasury bill rate in month $t$. We use market $_{t}$ in percentages in our analysis such that 2 means $2 \%$. market $_{t-j}$ is the $j-$ month lagged excess market returns. PTI, person-based trading index, is the measure of the common factor in the politicians' stock trades that Karadas et al. (forthcoming) calculate by aggregating all the transactions in the sample, following Jiang and Zaman (2010).

Karadas et al. (forthcoming) first sum the difference between the total number of buyers and the total number of sellers of a stock over the most recent three months and scale this sum by the total number of traders (buyers + sellers). Next, they average their findings across all the firms in a given month. Accordingly, $P T I_{t}$ includes transactions in 
months $t, t-1$, and $t-2$. Equations (2) and (3) demonstrate the construction of PTI in month $t$ :

$$
\operatorname{PTI}_{k, t}=\frac{\sum_{j=0}^{2} \text { AllBuyers }_{k, t-j}-\sum_{j=0}^{2} \text { AllSellers }_{k, t-j}}{\sum_{j=0}^{2} \text { AllBuyers }_{k, t-j}+\sum_{j=0}^{2} \text { AllSellers }_{k, t-j}}
$$

Here, $k$ is an index for firm $k$, and $j$ is an index for time lag. AllBuyers (AllSellers) equals the total number of traders who bought (sold) shares in the stock of firm $k$ in a given month. The next equation averages $P T I_{k, t}$ (PTI in a given firm-month) across $\mathrm{K}$ firms in month $t$ :

$$
P T I_{t}=\frac{\sum_{k=1}^{K} P T I_{k, t}}{K}
$$

It is important to elaborate on the purpose and the outcome of the aggregation process performed via Equations (2) and (3). Members of Congress could trade on an information set $s$ such that $s=\{f, i, m\}$ where $f, i$, and $m$ are firm-specific, industry-specific, and macroeconomic (i.e., economy-wide) information, respectively. The aggregation process, if done at the market-level, isolates the component $m$ (e.g., Seyhun 1988; Howe et al. 2009). If politicians' aggregated transactions do not include any economy-wide information, then we will not anticipate any relationship between their trades and stock market returns. For example, if politicians exclusively trade on firm-specific information such as a defense contractor receiving a large contract, the firm-specific components will cancel out during the aggregation process such that PTI will not be related to future stock market returns. However, to the extent that politicians' trades are driven by macroeconomic information, we should observe a relationship between politicians' aggregated stock trades and future stock market returns.

Equation (1) also include commonly used control variables in the literature. These variables are the 3-month Treasury bill rate (tb3mate), the default spread calculated as the yield difference between the BAA and AAA rated corporate debt (dspread), the term spread calculated as the difference between the 10-year Treasury bond yield and the 3-month Treasury bill rate (tspread), and the earnings to price ratio calculated as the log of 12-month moving sum of the earnings of the S\&P 500 firms minus the log of the S\&P 500 price level (epratio). ${ }^{4}$

The Karadas et al. (forthcoming) study has provided empirical evidence that politicians' aggregated trades predict stock market returns and that politicians' information on the future trajectory of the macroeconomy serves as the channel for this predictive ability. ${ }^{5}$ In particular, they document that the growth rate of industrial production is the mechanism by which aggregated trades by politicians predict the future stock market returns. They provide empirical support for this mechanism by first showing that politicians' aggregated trades are positively correlated with the future growth rates of industrial production and then by adding 1-month lagged growth rate of industrial production, pcind prod $_{t-1}$, to Equation (1). After adding this new variable, Karadas et al. (forthcoming) find that the coefficient of $P T I_{t-1}$ declines, but still remains statistically significant. We also add pcind prod $_{t-1}$, to Equation (1) and refer to the expanded equation as Equation (4):

$$
\begin{aligned}
& \text { market }_{t}=\beta_{0}+\beta_{1} \text { PTI }_{t-1}+\alpha_{1} \text { market }_{t-1}+\alpha_{2} \text { market }_{t-3}+\alpha_{3} \text { market }_{t-6} \\
& +\alpha_{4} \text { market }_{t-9}+\alpha_{5} \text { market }_{t-12}+\alpha_{6} \text { market }_{t-24}+\theta_{1} \text { tb3mrate }_{t-1}+\theta_{2} \text { dspread }_{t-1} \\
& +\theta_{3} \text { tspread }_{t-1}+\theta_{4} \text { epratio }_{t-1}+\theta_{5} \text { pcindprod }_{t-1}+\varepsilon_{t}
\end{aligned}
$$

PTI only focuses on the number of traders and ignores multiple buy or sell transactions made by the same politician in the same stock during the same month. To account for these multiple transactions, we employ an additional method of aggregation. In particular, we follow Seyhun (1988) who uses a standardized measure to capture both the firm-level and the aggregate-level insider trading. We slightly modify his method by constructing a 
transaction-based trading index (TTI) from congressional stock trades. Similar to PTI, we develop TTI in two steps. First, Equation (5) constructs a monthly firm-level trading index using the number of transactions instead of the number of traders:

$$
\operatorname{TTI}_{k, t}=\frac{\sum_{j=0}^{2} \text { NBuys }_{k, t-j}-\sum_{j=0}^{2} \text { NSell }_{k, t-j}}{\sum_{j=0}^{2} \text { NBuys }_{k, t-j}+\sum_{j=0}^{2} \text { SSell }_{k, t-j}}
$$

where $N B u y s_{k, t}$ and NSells $s_{k, t}$ are the total number of buy and sell transactions in firm $k^{\prime}$ s stock by politicians in month $t$. TTI significantly differs from PTI in treating individual transactions by incorporating all transactions made by the same politician in the same stock during the same month. For example, a politician might have bought IBM shares at six different times and sold them at eight different times in June 2014. These transactions would increase NBuys IBM,June2014 by six, and NSells $I B M$,June2014 by eight under TTI whereas they would increase AllBuyers IBM,June2014 and AllSellers IBM,June2014 only by one under PTI.

The second step averages the monthly firm-level TTI across firms for every month using Equation (6):

$$
T T I_{t}=\frac{\sum_{k=1}^{K} T T I_{k, t}}{K}
$$

where $K$ is the number of firms in month $t$.

The possibility exists that politicians trade with higher dollar volumes when they have more important information. To test this possibility, we develop a volume-based trading index (VTI) in a similar fashion to PTI and TTI. In another words, instead of using the number of politicians who traded a company's stock or the number of times that a company's shares were traded, we now focus on the dollar value of the transactions. We first derive a monthly firm-level trading index via Equation (7):

$$
\operatorname{VTI}_{k, t}=\frac{\sum_{j=0}^{2}{ }^{D B u y s} s_{k, t-j}-\sum_{j=0}^{2} \text { DSell }_{k, t-j}}{\sum_{j=0}^{2} D B u y s_{k, t-j}+\sum_{j=0}^{2} \text { DSell }_{k, t-j}}
$$

where $D B u y s_{k, t}$ and DSells $s_{k, t}$ are the total dollar value of buy and sell transactions in firm $k^{\prime}$ s stock in month $t$ in the sample period. Because most of the dollar amounts in politicians' FDRs are reported using intervals such as $\$ 50,000-\$ 100,000$ instead of specific dollar amounts, we use the midpoint of such intervals to represent the transaction values (Ziobrowski et al. 2004). The second step uses Equation (8) to average the firm-level VTI every month:

$$
V T I_{t}=\frac{\sum_{k=1}^{K} V T I_{k, t}}{K}
$$

where $K$ is the number of firms in month $t$.

To understand the data better, we present the descriptive statistics for all the variables used in the regression analysis in Table $1 .^{6}$ The average monthly excess returns over the sample period is positive with an approximate value of $0.54 \%$. The average value of $P T I_{t-1}$ is 0.0165 , which is lower than that of $T T I_{t-1}$ and $V T I_{t-1}$. However, all the main variables of interest $\left(P T I_{t-1}, T T I_{t-1}\right.$, and $\left.V T I_{t-1}\right)$ have similar standard deviations. They also have similar maximum and minimum values. Table 1 reports the 1 -month lagged values of the 3-month Treasury bill rate $\left(\right.$ tb3 $\left._{\text {mrate }}-1\right)$, the default spread $\left(\right.$ dspread $\left._{t-1}\right)$, and the the term spread $\left(\right.$ tspread $\left._{t-1}\right)$ on an annualized basis. The 3-month Treasury bill rate is $1.88 \%$ on average but reaches as high as $5.03 \%$. The default spread ranges from $0.62 \%$ to $3.38 \%$ with an average value of $1.17 \%$. The term spread has a larger dispersion, ranging from $-0.38 \%$ to $3.70 \%$ with an average value of $1.95 \%$. Earnings to price ratio is bounded between -1.9724 and -0.1873 with an average value of -0.6104 . Finally, the monthly growth rate of industrial production is $0.05 \%$ on average, fluctuating between $-4.30 \%$ and $1.56 \%$. 
Table 1. Descriptive statistics.

\begin{tabular}{ccccc}
\hline Variables & Mean & StdDev & Minimum & Maximum \\
\hline Market $_{t}$ & 0.5434 & 5.6876 & -20.6022 & 19.2661 \\
PTI $_{t-1}$ & 0.0165 & 0.1229 & -0.2282 & 0.4158 \\
TTI $_{t-1}$ & 0.0179 & 0.1228 & -0.2264 & 0.4288 \\
VTI $_{t-1}$ & 0.0219 & 0.1236 & -0.2494 & 0.4393 \\
Market $_{t-1}$ & 0.5918 & 5.7182 & -20.6022 & 19.2661 \\
Market $_{t-3}$ & 0.5446 & 5.6708 & -20.6022 & 19.2661 \\
Market $_{t-6}$ & 0.6139 & 5.6379 & -20.6022 & 19.2661 \\
Market $_{t-9}$ & 1.0637 & 5.6362 & -20.6022 & 19.2661 \\
Market $_{t-12}$ & 1.1726 & 5.6939 & -20.6022 & 19.2661 \\
Market $_{t-24}$ & 0.8345 & 5.8617 & -20.6022 & 19.2661 \\
tb3rrate $_{t-1}$ & 1.8750 & 1.8541 & 0.0100 & 5.0300 \\
dspread $_{t-1}$ & 1.1697 & 0.5839 & 0.6200 & 3.3800 \\
tspread $_{t-1}$ & 1.9499 & 1.2716 & -0.3800 & 3.7000 \\
epratio $_{t-1}$ & -0.6104 & 0.3789 & -1.9724 & -0.1873 \\
pindprod $_{t-1}$ & 0.0465 & 0.8574 & -4.3029 & 1.5567
\end{tabular}

Notes: This table presents the descriptive statistics for the monthly variables used in the regressions where we investigate whether politicians' aggregated transactions predict future stock market returns during the Pre-STOCK Act period (January 2004 to March 2012). $t$ refers to month $t$, and $t-1$ is the 1-month lagged value. The main variables of interest are the Person-Based Trading Index (PTI), Transactions-Based Trading Index (TTI), and the VolumeBased Trading Index (VTI). The starting point for PTI is Equation (2), $P T I_{k, t}=\frac{\sum_{j=0}^{2} \text { AllBuyers } k, t-j_{-\sum_{j=0}^{2} \text { AllSellers }_{k, t-j}}}{\sum_{j=0}^{2} \text { AllBuyers }_{k, t-j}+\sum_{j=0}^{2} \text { Allsellers }_{k, t-j}}$, where $k$ is an index for firm $k$, and $j$ is an index for time lag. AllBuyers (AllSellers) equals the total number of traders who bought (sold) shares in the stock of firm $k$ in a given month. Equation (3) averages $P T I_{k, t}$ across $\mathrm{K}$ firms in month $t$ and produces the series that are used in the regression analysis: $P T I_{t}=\frac{\sum_{k=1}^{K} P T I_{k, t}}{K}$. The starting point for TTI is Equation (5), TTI $I_{k, t}=\frac{\sum_{j=0}^{2} N B u y s_{k, t-j}-\sum_{j=0}^{2} N \text { Sell }_{k, t-j}}{\sum_{j=0}^{2} N B u y s_{k, t-j}+\sum_{j=0}^{2} N \text { ell }_{k, t-j}}$, where NBuys $s_{k, t}$ and NSells $s_{k, t}$ are the total number of buy and sell transactions in firm $k^{\prime}$ s stock by politicians in month $t$. Equation (6) averages $T T I_{k, t}$ across $\mathrm{K}$ firms in month $t$ and produces the series that are used in the regression analysis: $T T I_{t}=\frac{\sum_{k=1}^{K} T T I_{k, t}}{K}$. The starting point for VTI is Equation (7), VTI $I_{k, t}=\frac{\sum_{j=0}^{2} D B u y s_{k, t-j}-\sum_{j=0}^{2} D \text { Sells }_{k, t-j}}{\sum_{j=0}^{2} D B u y s_{k, t-j}+\sum_{j=0}^{2} D S e l s_{k, t-j}}$, where DBuys $s_{k, t}$ and DSells $s_{k, t}$ are the total dollar value of buy and sell transactions in firm $k^{\prime}$ s stock in month $t$ in the sample period. Equation (8) averages $V T I_{k, t}$ across $\mathrm{K}$ firms in month $t$ and produces the series that are used in the regression analysis: $V T I_{t}=\frac{\sum_{k=1}^{K} V T I_{k, t}}{K}$ market $_{t}$ is the dependent variable that we calculate as the return on the CRSP equal-weighted market index minus 1-month Treasury bill rate in month $t$. market $_{t-j}$ is the $j-$ month lagged excess market returns. Other variables are: the 3-month Treasury bill rate (tb3mate), the default spread calculated as the difference in the yields between the BAA and AAA rated corporate debt (dspread), the term spread calculated as the difference between the 10-year Treasury bond yield and the 3-month Treasury bill rate (tspread), the earnings to price ratio calculated as the log of 12-month moving sum of the earnings of the S\&P 500 firms minus the log of the S\&P 500 price level (epratio), and the rate at which industrial production grows (pcindprod).

It is important to discuss the data restrictions and limitations of this study. Since we are focused on predicting US stock market returns, our sample only includes transactions by politicians on domestic common stocks. This choice is consistent with the prior literature (Karadas 2019; Ziobrowski et al. 2004). There are also two limitations to note. The first is unreported transactions. Politicians sometimes do not report their transactions, violating the disclosure requirements required by law. For example, Slodysko (2021) reports that a member of U.S. House of Representatives failed to report his stock transactions during the Covid-19 pandemic in a timely fashion (in the amount of millions of dollars). Earlier, Mullins (2015) reported a similar violation for a member of the U.S. Senate. Politicians in these situations typically describe unreported transactions as filing errors. Were these errors made randomly or were politicians hiding their sensitive portfolio information? Answering these questions will require a systematic examination of all the unreported transactions. Unfortunately, the data on these violations are anecdotal, and we may never truly know all the unreported transactions. However, to the extent that politicians fail to disclose well-timed trades, our results will under-report the extent of informational advantage enjoyed by members of Congress. On the other hand, to the extent that politicians fail to disclose poorly-timed trades, our results will over-report the extent of informational advantage members of Congress possess. 
The second limitation are transactions with no valid date, which are dropped from the analysis. This is likely to be a benign limitation based on previous research. Karadas (2019) conducts an examination of such partially complete transactions (no-date sample) over the 2004-2010 period and comes to the conclusion that (p. 94) "there does not appear to be a systematic exclusion of transaction dates by a select group of politicians (given that the overwhelming majority of the politicians in the no-date sample also reported transactions with valid dates) or for a select group of securities (given that most of the securities in the no-date sample also appear in the final sample with a valid date)".

\section{Empirical Results}

To test the effect on the STOCK Act on the predictive ability of politicians' aggregated stock transactions, we estimated our predictive regressions over two periods: January 2004 to March 2012 (pre-STOCK Act period) and January 2004 to December 2014 (complete period). These estimations were based on 76,182 transactions over the pre-STOCK Act period, and 101,191 transactions over the complete period. We avoided running separate regressions for the post-STOCK Act period (May 2012 to December 2014) due to short time series. If the predictive ability of politicians' aggregated transactions weakened as we added more recent transactions, we interpreted this as the STOCK Act affecting the way that members of Congress traded stocks. Such a finding is consistent with view that nonpublic macroeconomic information explains the ability of politicians' aggregated transactions in predicting the stock market returns.

To help derive the economic significance of the results, we used the standard deviation of $P T I_{t-1}$. This value is available in Table 1 for the pre-STOCK Act period (0.1229) and was calculated to be 0.1197 for the complete period. We show the results based on PTI for the Pre-STOCK Act period and complete period in Table 2 where Model I and Model II represent Equations (1) and (4), respectively. For the Pre-STOCK Act period, the coefficient of $P T I_{t-1}$ was statistically significant at the $1 \%$ level under Model I, and for every one standard deviation increase in $P T I_{t-1}$, there was an increase of $1.73 \%(0.1229 \times 14.064)$ in market $_{t}$, excess market returns in month $t$. After controlling for the growth rate of industrial production under Model II, the coefficient of PTI loses some statistical significance (now significant at the $5 \%$ level), and one-standard deviation change in $P T I_{t-1}$ was associated with a $1.26 \%(0.1229 \times 10.222)$ change in market $_{t}$. For the complete period, the coefficient of $P \mathrm{PI}_{t-1}$ was statistically significant at the $5 \%$ level under Model I, and there was a $0.92 \%$ $(0.1197 \times 7.724)$ increase in market $_{t}$ for every one standard deviation increase in $P T I_{t-1}$. Under Model II, we only had marginal statistical significance (at the $10 \%$ level), and for every one standard deviation increase in $P T I_{t-1}$, there was a $0.62 \%(0.1197 \times 5.194)$ increase in the excess market returns. Similar to what we observed during the Pre-STOCK Act period, the coefficient on $\mathrm{PTI}_{t-1}$ deteriorated in terms of both statistical and economic significance when we went from Model I to Model II. Overall, the coefficients on $P T I_{t-1}$ over the complete period were about half the magnitudes of those that we observed over the Pre-STOCK Act period. 
Table 2. Person-based trading index and equal-weighted market returns.

\begin{tabular}{|c|c|c|c|c|}
\hline \multirow[b]{2}{*}{ Variables } & \multicolumn{2}{|c|}{ Pre-STOCK Act Period } & \multicolumn{2}{|c|}{ Complete Period } \\
\hline & Model I & Model II & Model I & Model II \\
\hline Intercept & $\begin{array}{l}0.432 \\
(0.12)\end{array}$ & $\begin{array}{l}-1.399 \\
(-0.36)\end{array}$ & $\begin{array}{c}4.034^{* *} \\
(2.05)\end{array}$ & $\begin{array}{l}2.017 \\
(0.99)\end{array}$ \\
\hline$P T I_{t-1}$ & $\begin{array}{c}14.064^{* * *} \\
(2.81)\end{array}$ & $\begin{array}{c}10.222 * * \\
(2.50)\end{array}$ & $\begin{array}{l}7.724^{* *} \\
(2.07)\end{array}$ & $\begin{array}{l}5.194 \text { * } \\
(1.71)\end{array}$ \\
\hline Market $_{t-1}$ & $\begin{array}{l}0.155 \\
(1.57)\end{array}$ & $\begin{array}{l}0.169 \\
(1.66)\end{array}$ & $\begin{array}{l}0.139 \\
(1.46)\end{array}$ & $\begin{array}{l}0.152 \\
(1.55)\end{array}$ \\
\hline Market $_{t-3}$ & $\begin{array}{l}0.137 \\
(1.37)\end{array}$ & $\begin{array}{l}0.095 \\
(0.96)\end{array}$ & $\begin{array}{l}0.112 \\
(1.30)\end{array}$ & $\begin{array}{l}0.085 \\
(1.01)\end{array}$ \\
\hline Market $_{t-6}$ & $\begin{array}{l}-0.330^{* *} \\
(-2.43)\end{array}$ & $\begin{array}{l}-0.320 * * \\
(-2.57)\end{array}$ & $\begin{array}{l}-0.279 * * \\
(-2.30)\end{array}$ & $\begin{array}{l}-0.270 \text { ** } \\
(-2.36)\end{array}$ \\
\hline Market $_{t-9}$ & $\begin{array}{l}-0.026 \\
(-0.31)\end{array}$ & $\begin{array}{l}-0.055 \\
(-0.71)\end{array}$ & $\begin{array}{l}-0.024 \\
(-0.35)\end{array}$ & $\begin{array}{l}-0.046 \\
(-0.70)\end{array}$ \\
\hline Market $_{t-12}$ & $\begin{array}{l}0.032 \\
(0.45)\end{array}$ & $\begin{array}{l}0.044 \\
(0.65)\end{array}$ & $\begin{array}{l}0.033 \\
(0.53)\end{array}$ & $\begin{array}{l}0.039 \\
(0.62)\end{array}$ \\
\hline Market $_{t-24}$ & $\begin{array}{l}-0.146 \\
(-1.62)\end{array}$ & $\begin{array}{l}-0.127 \\
(-1.47)\end{array}$ & $\begin{array}{l}-0.093 \\
(-1.31)\end{array}$ & $\begin{array}{l}-0.075 \\
(-1.09)\end{array}$ \\
\hline tb3mrate t-1 $_{1}$ & $\begin{array}{l}-0.258 \\
(-0.37)\end{array}$ & $\begin{array}{l}-0.173 \\
(-0.24)\end{array}$ & $\begin{array}{c}-1.019 * * * \\
(-2.76)\end{array}$ & $\begin{array}{l}-0.864^{* *} \\
(-2.36)\end{array}$ \\
\hline dspread $_{t-1}$ & $\begin{array}{l}0.395 \\
(0.38)\end{array}$ & $\begin{array}{l}1.921 \\
(1.58)\end{array}$ & $\begin{array}{l}-0.108 \\
(-0.11)\end{array}$ & $\begin{array}{l}1.324 \\
(1.28)\end{array}$ \\
\hline tspread $_{t-1}$ & $\begin{array}{l}-1.373 \\
(-1.39)\end{array}$ & $\begin{array}{l}-1.079 \\
(-1.07)\end{array}$ & $\begin{array}{c}-2.024 * * * \\
(-2.85)\end{array}$ & $\begin{array}{c}-1.677^{* *} \\
(-2.41)\end{array}$ \\
\hline epratio $_{t-1}$ & $\begin{array}{c}-4.466^{* * *} \\
(-4.90)\end{array}$ & $\begin{array}{c}-3.299 * * * \\
(-2.86)\end{array}$ & $\begin{array}{c}-4.128^{* * *} \\
(-4.94)\end{array}$ & $\begin{array}{c}-3.045^{* * * *} \\
(-3.08)\end{array}$ \\
\hline pcindprod $_{t-1}$ & & $\begin{array}{c}2.161^{* * *} \\
(3.19)\end{array}$ & & $\begin{array}{c}1.964^{* * *} \\
(2.64)\end{array}$ \\
\hline $\operatorname{Adj} R^{2}$ & 21.62 & 28.11 & 14.18 & 19.72 \\
\hline
\end{tabular}

Notes: This table reports the results on the regressions where we investigate whether politicians' aggregated transactions predict future stock market returns. Results are presented separately for the period preceding the STOCK Act (January 2004 to March 2012) and for the full sample period (January 2004 to December 2014). The main variable of interest is the Person-Based Trading Index (PTI). The starting point for PTI is Equation (2), $P T I_{k, t}=\frac{\sum_{j=0}^{2} \text { AllBuyers }_{k, t-j}-\sum_{j=0}^{2} \text { Allsellers }_{k, t-j}}{\sum_{j=0}^{2} \text { AllBuyers }_{k, t-j}+\sum_{j=0}^{2} \text { Allseller }_{k, t-j}}$, where $k$ is an index for firm $k$, and $j$ is an index for time lag. AllBuyers (AllSellers) equals the total number of traders who bought (sold) shares in the stock of firm $k$ in a given month Equation (3) averages $P T I_{k, t}$ across $\mathrm{K}$ firms in month $t$ and produces the series that are used in the regression analysis: $P T I_{t}=\frac{\sum_{k=1}^{K} P T I_{k, t}}{K}$. market $_{t}$ is the dependent variable that we calculate as the return on the CRSP equalweighted market index minus 1-month Treasury bill rate in month $t$. market $_{t-j}$ is the $j-$ month lagged excess market returns. Other variables are: the 3-month Treasury bill rate (tb3mate), the default spread calculated as the difference in the yields between the BAA and AAA rated corporate debt (dspread), the term spread calculated as the difference between the 10-year Treasury bond yield and the 3-month Treasury bill rate (tspread), the earnings to price ratio calculated as the log of 12-month moving sum of the earnings of the S\&P 500 firms minus the log of the S\&P 500 price level (epratio), and the rate at which industrial production grows (pcindprod). We report the $\mathrm{t}$-statistics in parenthesis that are robust for heteroskedasticity and autocorrelation and based on three lags. The level of significance at the $1 \%, 5 \%$, and $10 \%$ are demonstrated with ${ }^{* * *}, * *$, and ${ }^{*}$, respectively.

We now proceed to the discussion of the results based on TTI. The standard deviation of $T_{T} I_{t-1}$ was 0.1228 (see Table 1) in the Pre-STOCK Act period and was calculated to be 0.1193 in the complete period. We present the results based on TTI in Table 3 . In the Pre-STOCK Act period, the coefficient on $T T I_{t-1}$ was statistically significant at the $1 \%$ level under Model I and at the 5\% level under Model II. Furthermore, one-standard deviation increase in $T T I_{t-1}$ was associated with a $1.69 \%(0.1228 \times 13.748)$ and a $1.21 \%(0.1228 \times$ 9.843) increase in market $_{t}$ under Model I and Model II, respectively. For the complete period, the results from Model I show that the coefficient on $T T I_{t-1}$ was statistically significant at the $5 \%$ level, and one-standard deviation change in $T T I_{t-1}$ is associated with a $0.92 \%$ $(0.1193 \times 7.726)$ change in the excess market returns. When we switched from Model I to Model II, the coefficient on our variable of interest declined in magnitude, and it was no longer statistically significant. 
Table 3. Transactions-based trading index and equal-weighted market returns.

\begin{tabular}{|c|c|c|c|c|}
\hline \multirow[b]{2}{*}{ Variables } & \multicolumn{2}{|c|}{ Pre-STOCK Act Period } & \multicolumn{2}{|c|}{ Complete Period } \\
\hline & Model I & Model II & Model I & Model II \\
\hline Intercept & $\begin{array}{l}0.901 \\
(0.26)\end{array}$ & $\begin{array}{l}-1.027 \\
(-0.27)\end{array}$ & $\begin{array}{c}4.183^{* *} \\
(2.11)\end{array}$ & $\begin{array}{l}2.112 \\
(1.03)\end{array}$ \\
\hline$T T I_{t-1}$ & $\begin{array}{l}13.748^{* * *} \\
(2.65)\end{array}$ & $\begin{array}{l}9.843 * * \\
(2.36)\end{array}$ & $\begin{array}{l}7.726^{* *} \\
(2.00)\end{array}$ & $\begin{array}{l}5.134 \\
(1.65)\end{array}$ \\
\hline Market $_{t-1}$ & $\begin{array}{l}0.158 \\
(1.61)\end{array}$ & $\begin{array}{c}0.171^{*} \\
(1.69)\end{array}$ & $\begin{array}{l}0.141 \\
(1.47)\end{array}$ & $\begin{array}{l}0.154 \\
(1.56)\end{array}$ \\
\hline Market $_{t-3}$ & $\begin{array}{l}0.137 \\
(1.37)\end{array}$ & $\begin{array}{l}0.095 \\
(0.96)\end{array}$ & $\begin{array}{l}0.111 \\
(1.28)\end{array}$ & $\begin{array}{l}0.085 \\
(1.00)\end{array}$ \\
\hline Market $_{t-6}$ & $\begin{array}{l}-0.329^{* *} \\
(-2.42)\end{array}$ & $\begin{array}{l}-0.320 * * \\
(-2.55)\end{array}$ & $\begin{array}{l}-0.277^{* *} \\
(-2.29)\end{array}$ & $\begin{array}{c}-0.269^{* *} \\
(-2.35)\end{array}$ \\
\hline Market $_{t-9}$ & $\begin{array}{l}-0.025 \\
(-0.30)\end{array}$ & $\begin{array}{l}-0.055 \\
(-0.69)\end{array}$ & $\begin{array}{l}-0.024 \\
(-0.36)\end{array}$ & $\begin{array}{l}-0.047 \\
(-0.70)\end{array}$ \\
\hline Market $_{t-12}$ & $\begin{array}{l}0.027 \\
(0.37)\end{array}$ & $\begin{array}{l}0.040 \\
(0.59)\end{array}$ & $\begin{array}{l}0.032 \\
(0.50)\end{array}$ & $\begin{array}{l}0.037 \\
(0.60)\end{array}$ \\
\hline Market $_{t-24}$ & $\begin{array}{l}-0.147 \\
(-1.64)\end{array}$ & $\begin{array}{l}-0.127 \\
(-1.49)\end{array}$ & $\begin{array}{l}-0.094 \\
(-1.32)\end{array}$ & $\begin{array}{l}-0.076 \\
(-1.10)\end{array}$ \\
\hline tb3mrate t-1 $_{1}$ & $\begin{array}{l}-0.282 \\
(-0.39)\end{array}$ & $\begin{array}{l}-0.200 \\
(-0.27)\end{array}$ & $\begin{array}{c}-1.012 * * * \\
(-2.74)\end{array}$ & $\begin{array}{l}-0.859^{* *} \\
(-2.35)\end{array}$ \\
\hline dspread $_{t-1}$ & $\begin{array}{l}0.121 \\
(0.11)\end{array}$ & $\begin{array}{l}1.727 \\
(1.44)\end{array}$ & $\begin{array}{l}-0.238 \\
(-0.24)\end{array}$ & $\begin{array}{l}1.240 \\
(1.20)\end{array}$ \\
\hline tspread $_{t-1}$ & $\begin{array}{l}-1.375 \\
(-1.37)\end{array}$ & $\begin{array}{l}-1.085 \\
(-1.06)\end{array}$ & $\begin{array}{c}-2.012 * * * \\
(-2.85)\end{array}$ & $\begin{array}{c}-1.666^{* *} \\
(-2.40)\end{array}$ \\
\hline epratio $_{t-1}$ & $\begin{array}{c}-4.285^{* * *} \\
(-4.82)\end{array}$ & $\begin{array}{c}-3.151^{* * * *} \\
(-2.75)\end{array}$ & $\begin{array}{l}-4.051^{* * *} \\
(-4.91)\end{array}$ & $\begin{array}{c}-2.986^{* * * *} \\
(-3.03)\end{array}$ \\
\hline pcindprod $_{t-1}$ & & $\begin{array}{c}2.172^{* * *} \\
(3.25)\end{array}$ & & $\begin{array}{c}1.967^{* * *} \\
(2.66)\end{array}$ \\
\hline $\operatorname{Adj} R^{2}$ & 21.31 & 27.87 & 14.11 & 19.66 \\
\hline
\end{tabular}

Notes: This table reports the results on the regressions where we investigate whether politicians' aggregated transactions predict future stock market returns. Results are presented separately for the period preceding the STOCK Act (January 2004 to March 2012) and for the full sample period (January 2004 to December 2014). The main variable of interest is the Transactions-Based Trading Index (TTI). The starting point for TTI is Equation (5), $T T I_{k, t}=\frac{\sum_{j=0}^{2} N B u y s_{k, t-j}-\sum_{j=0}^{2} \text { NSell }_{k, t-j}}{\sum_{j=0}^{2} N B u y s_{k, t-j}+\sum_{j=0}^{2} \text { NSell }_{k, t-j}}$, where NBuys $s_{k, t}$ and NSells $s_{k, t}$ are the total number of buy and sell transactions in firm $k^{\prime}$ s stock by politicians in month $t$. Equation (6) averages $T T I_{k, t}$ across $\mathrm{K}$ firms in month $t$ and produces the series that are used in the regression analysis: $T T I_{t}=\frac{\sum_{k=1}^{K} T T I_{k, t}}{K}$. market $_{t}$ is the dependent variable that we calculate as the return on the CRSP equal-weighted market index minus 1-month Treasury bill rate in month $t$. market $t_{t-j}$ is the $j-$ month lagged excess market returns. Other variables are: the 3-month Treasury bill rate (tb3mate), the default spread calculated as the difference in the yields between the BAA and AAA rated corporate debt (dspread), the term spread calculated as the difference between the 10-year Treasury bond yield and the 3-month Treasury bill rate (tspread), the earnings to price ratio calculated as the log of 12 -month moving sum of the earnings of the S\&P 500 firms minus the log of the S\&P 500 price level (epratio), and the rate at which industrial production grows (pcindprod). We report the t-statistics in parenthesis that are robust for heteroskedasticity and autocorrelation and based on three lags. The level of significance at the $1 \%, 5 \%$, and $10 \%$ are demonstrated with ${ }^{* * *}, * *$, and *, respectively.

Does the trading volume contain information? We now address this question. The standard deviation of $V T I_{t-1}$ was 0.1236 from Table 1 in the Pre-STOCK Act period and was determined to be 0.1210 in the complete period. We report the regression results in Table 4. For the Pre-STOCK Act period, the coefficient on $V T I_{t-1}$ was statistically significant at the $1 \%$ level across both models. Further, one-standard deviation change in $V T I_{t-1}$ was associated with a $1.87 \%(0.1236 \times 15.103)$ and a $1.40 \%(0.1236 \times 11.303)$ change in market $t_{t}$ under Models I and II, respectively. For the complete period, the coefficient on $V T I_{t-1}$ was significant across both models (but only marginally under Model II), and one-standard deviation change in $V T I_{t-1}$ corresponded to a $1.03 \%(0.1210 \times 8.492)$ and a $0.72 \%(0.1210 \times 5.973)$ change in market $_{t}$ under Models I and II, respectively. 
Table 4. Volume-based trading index and equal-weighted market returns.

\begin{tabular}{|c|c|c|c|c|}
\hline \multirow[b]{2}{*}{ Variables } & \multicolumn{2}{|c|}{ Pre-STOCK Act Period } & \multicolumn{2}{|c|}{ Complete Period } \\
\hline & Model I & Model II & Model I & Model II \\
\hline Intercept & $\begin{array}{l}-0.062 \\
(-0.02)\end{array}$ & $\begin{array}{l}-1.825 \\
(-0.47)\end{array}$ & $\begin{array}{c}3.636^{*} \\
(1.81)\end{array}$ & $\begin{array}{l}1.431 \\
(0.69)\end{array}$ \\
\hline$V T I_{t-1}$ & $\begin{array}{c}15.103^{* * *} \\
(3.04)\end{array}$ & $\begin{array}{c}11.303^{* * * *} \\
(2.65)\end{array}$ & $\begin{array}{c}8.492 * * \\
(2.19)\end{array}$ & $\begin{array}{c}5.973 * \\
(1.83)\end{array}$ \\
\hline Market $_{t-1}$ & $\begin{array}{l}0.151 \\
(1.49)\end{array}$ & $\begin{array}{l}0.165 \\
(1.59)\end{array}$ & $\begin{array}{c}0.144 \\
(1.48)\end{array}$ & $\begin{array}{l}0.159 \\
(1.59)\end{array}$ \\
\hline Market $_{t-3}$ & $\begin{array}{l}0.129 \\
(1.26)\end{array}$ & $\begin{array}{l}0.089 \\
(0.89)\end{array}$ & $\begin{array}{l}0.109 \\
(1.27)\end{array}$ & $\begin{array}{l}0.084 \\
(0.99)\end{array}$ \\
\hline Market $_{t-6}$ & $\begin{array}{c}-0.323^{* *} \\
(-2.42)\end{array}$ & $\begin{array}{c}-0.315^{* *} \\
(-2.56)\end{array}$ & $\begin{array}{c}-0.279 * * \\
(-2.34)\end{array}$ & $\begin{array}{c}-0.274^{* *} \\
(-2.43)\end{array}$ \\
\hline Market $_{t-9}$ & $\begin{array}{l}-0.030 \\
(-0.35)\end{array}$ & $\begin{array}{l}-0.058 \\
(-0.73)\end{array}$ & $\begin{array}{l}-0.024 \\
(-0.35)\end{array}$ & $\begin{array}{l}-0.046 \\
(-0.68)\end{array}$ \\
\hline Market $_{t-12}$ & $\begin{array}{l}0.027 \\
(0.38)\end{array}$ & $\begin{array}{l}0.039 \\
(0.59)\end{array}$ & $\begin{array}{l}0.023 \\
(0.35)\end{array}$ & $\begin{array}{l}0.025 \\
(0.40)\end{array}$ \\
\hline Market $_{t-24}$ & $\begin{array}{c}-0.148^{*} \\
(-1.69)\end{array}$ & $\begin{array}{l}-0.129 \\
(-1.54)\end{array}$ & $\begin{array}{l}-0.093 \\
(-1.33)\end{array}$ & $\begin{array}{l}-0.075 \\
(-1.10)\end{array}$ \\
\hline tb3mrate t-1 $_{1}$ & $\begin{array}{l}-0.217 \\
(-0.31)\end{array}$ & $\begin{array}{l}-0.126 \\
(-0.18)\end{array}$ & $\begin{array}{c}-0.953^{\text {** }} \\
(-2.49)\end{array}$ & $\begin{array}{c}-0.751^{* *} \\
(-2.03)\end{array}$ \\
\hline dspread $_{t-1}$ & $\begin{array}{l}0.462 \\
(0.43)\end{array}$ & $\begin{array}{l}1.958 \\
(1.60)\end{array}$ & $\begin{array}{l}-0.091 \\
(-0.09)\end{array}$ & $\begin{array}{l}1.387 \\
(1.34)\end{array}$ \\
\hline tspread $_{t-1}$ & $\begin{array}{l}-1.369 \\
(-1.42)\end{array}$ & $\begin{array}{l}-1.069 \\
(-1.07)\end{array}$ & $\begin{array}{c}-1.943^{* * * *} \\
(-2.75)\end{array}$ & $\begin{array}{c}-1.523 \text { ** } \\
(-2.21)\end{array}$ \\
\hline epratio $_{t-1}$ & $\begin{array}{c}-4.868^{* * *} \\
(-4.95)\end{array}$ & $\begin{array}{c}-3.638^{* * *} \\
(-3.01)\end{array}$ & $\begin{array}{c}-4.216^{* * *} \\
(-4.89)\end{array}$ & $\begin{array}{c}-2.999 * * * \\
(-2.92)\end{array}$ \\
\hline pcindprod $_{t-1}$ & $2.130 * * *$ & (3.09) & $2.027 * * *$ & $(2.78)$ \\
\hline $\operatorname{Adj} R^{2}$ & 22.44 & 28.73 & 14.80 & 20.73 \\
\hline
\end{tabular}

Notes: This table reports the results on the regressions where we investigate whether politicians' aggregated transactions predict future stock market returns. Results are presented separately for the period preceding the STOCK Act (January 2004 to March 2012) and for the full sample period (January 2004 to December 2014). The main variable of interest is the Volume-Based Trading Index (VTI). The starting point for VTI is Equation (7), $V T I_{k, t}=\frac{\sum_{j=0}^{2} D B u y s_{k, t-j}-\sum_{j=0}^{2} D \text { Sells }_{k, t-j}}{\sum_{j=0}^{2} D B u y s_{k, t-j}+\sum_{j=0}^{2} D \text { Sell }_{k, t-j}}$, where DBuys $k, t$ and DSells $s_{k, t}$ are the total dollar value of buy and sell transactions in firm $k^{\prime}$ s stock in month $t$ in the sample period. Equation (8) averages $V T I_{k, t}$ across $\mathrm{K}$ firms in

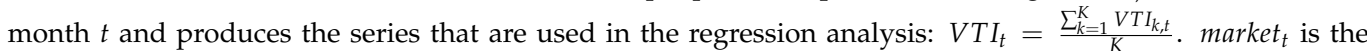
dependent variable that we calculate as the return on the CRSP equal-weighted market index minus 1-month Treasury bill rate in month $t$. market $_{t-j}$ is the $j-$ month lagged excess market returns. Other variables are: the 3-month Treasury bill rate (tb3mate), the default spread calculated as the difference in the yields between the BAA and AAA rated corporate debt (dspread), the term spread calculated as the difference between the 10-year Treasury bond yield and the 3-month Treasury bill rate (tspread), the earnings to price ratio calculated as the log of 12-month moving sum of the earnings of the S\&P 500 firms minus the log of the S\&P 500 price level (epratio), and the rate at which industrial production grows (pcindprod). We report the $t$-statistics in parenthesis that are robust for heteroskedasticity and autocorrelation and based on three lags. The level of significance at the $1 \%, 5 \%$ and $10 \%$ are demonstrated with ${ }^{* * *}, * *$, and $*$, respectively.

Overall, the empirical results suggest that PTI, TTI, and VTI contained similar levels of macroeconomic information. Furthermore, the predictive ability of politicians' aggregated trades got weaker after including the post-STOCK Act transactions in the sample. We interpret the weakening in the coefficients of $P T I_{t-1}, T T I_{t-1}$, and $V T I_{t-1}$, both in terms of economic and statistical significance, as evidence in favor of the argument that STOCK Act impacted the extent to which politicians used nonpublic macroeconomic information in their stock transactions. In the Pre-STOCK Act period, our key variables of interest declined in economic significance in all cases and statistical significance in some cases after controlling for pcindprod $_{t-1}$, however they remained statistically significant at the $5 \%$ level or better. This result is in line with the Karadas et al. (forthcoming) study in that industrial production captures only some of the macroeconomic information that politicians use in their trades. On the other hand, switching from Model I to Model II in 
the complete period led to marginal statistical significance in the coefficients of $P T I_{t-1}$ and $V T I_{t-1}$ and statistical insignificance in the coefficient of $T T I_{t-1}$. The latter results suggest that the information content of transactions-based trading index was now completely subsumed by the growth rate of industrial production, and other potential macroeconomic channels that existed before the STOCK Act (besides the industrial production) were affected by the passage of the STOCK Act.

\section{Robustness Checks}

\subsection{Small versus Large Stocks}

Are the empirical results in this study driven by small stocks? We attempt to address this concern in this section. In their seminal paper, Lakonishok and Lee (2001), using transactions made by corporate insiders, find that insiders' aggregated transactions have a better predictive ability when it comes to the returns on small stocks than large stocks. Lakonishok and Lee (2001, p. 94) argue that "managers in smaller firms possess more valuable information about the fortunes of their companies than do the managers of larger firms".

The possibility exists that macroeconomic information contained in politicians' trades could have been mostly concentrated in small stocks. To account for the possibility, we used the value-weighted excess market returns (calculated as the returns on the CRSP value-weighted market index minus the 1-month Treasury bill rate) as the dependent variable. This new dependent variable was less affected by the small market capitalization stocks than than the prior dependent variable.

We re-estimated Equations (1) and (4) and report the results for $P T I_{t-1}$ in Table 5, $T T I_{t-1}$ in Table 6, and $V T I_{t-1}$ in Table 7. Over the Pre-STOCK Act period, when the key variable of interest was the person-based transactions index $\left(P T I_{t-1}\right)$, the coefficient on this variable was statistically significant at the $1 \%$ level across models, and one standard deviation increase corresponded to a $1.54 \%(0.1229 \times 12.509)$ and a $1.04 \%(0.1229 \times 8.446)$ increase in the excess market returns under Model I and Model II, respectively. When the relevant sample was the complete period, the coefficient on $P T I_{t-1}$ was statistically significant at the 5\% level under Model I and at the 10\% level under Model II. Furthermore, for every one standard deviation increase in $P T I_{t-1}$, we observed a $0.81 \%(0.1197 \times 6.757)$ and a $0.50 \%(0.1197 \times 4.216)$ increase in market $_{t}$ under Model I and Model II, respectively. 
Table 5. Person-based trading index and value-weighted market returns.

\begin{tabular}{|c|c|c|c|c|}
\hline \multirow[b]{2}{*}{ Variables } & \multicolumn{2}{|c|}{ Pre-STOCK Act Period } & \multicolumn{2}{|c|}{ Complete Period } \\
\hline & Model I & Model II & Model I & Model II \\
\hline Intercept & $\begin{array}{l}3.567 \\
(1.21)\end{array}$ & $\begin{array}{l}1.838 \\
(0.60)\end{array}$ & $\begin{array}{c}6.310^{* * *} \\
(3.51)\end{array}$ & $\begin{array}{c}4.314^{* *} \\
(2.27)\end{array}$ \\
\hline$P T I_{t-1}$ & $\begin{array}{c}12.509^{* * *} \\
(3.06)\end{array}$ & $\begin{array}{c}8.446^{* * *} \\
(2.70)\end{array}$ & $\begin{array}{l}6.757 * * \\
(2.24)\end{array}$ & $\begin{array}{l}4.216^{*} \\
(1.77)\end{array}$ \\
\hline Market $_{t-1}$ & $\begin{array}{l}0.068 \\
(0.70)\end{array}$ & $\begin{array}{l}0.081 \\
(0.80)\end{array}$ & $\begin{array}{l}0.060 \\
(0.64)\end{array}$ & $\begin{array}{l}0.071 \\
(0.73)\end{array}$ \\
\hline Market $_{t-3}$ & $\begin{array}{l}0.008 \\
(0.07)\end{array}$ & $\begin{array}{l}-0.057 \\
(-0.51)\end{array}$ & $\begin{array}{l}0.017 \\
(0.19)\end{array}$ & $\begin{array}{l}-0.020 \\
(-0.25)\end{array}$ \\
\hline Market $_{t-6}$ & $\begin{array}{l}-0.335^{* *} \\
(-2.40)\end{array}$ & $\begin{array}{l}-0.304^{* *} \\
(-2.48)\end{array}$ & $\begin{array}{l}-0.275^{* *} \\
(-2.30)\end{array}$ & $\begin{array}{l}-0.252^{* *} \\
(-2.29)\end{array}$ \\
\hline Market $_{t-9}$ & $\begin{array}{l}-0.158 \\
(-1.29)\end{array}$ & $\begin{array}{l}-0.220 * * \\
(-2.25)\end{array}$ & $\begin{array}{l}-0.109 \\
(-1.15)\end{array}$ & $\begin{array}{l}-0.152 * \\
(-1.88)\end{array}$ \\
\hline Market $_{t-12}$ & $\begin{array}{l}0.065 \\
(0.73)\end{array}$ & $\begin{array}{l}0.097 \\
(1.28)\end{array}$ & $\begin{array}{l}0.037 \\
(0.46)\end{array}$ & $\begin{array}{l}0.056 \\
(0.76)\end{array}$ \\
\hline Market $_{t-24}$ & $\begin{array}{l}-0.218^{* *} \\
(-2.42)\end{array}$ & $\begin{array}{l}-0.191^{* *} \\
(-2.23)\end{array}$ & $\begin{array}{l}-0.109 \\
(-1.50)\end{array}$ & $\begin{array}{l}-0.083 \\
(-1.19)\end{array}$ \\
\hline tb3mrate t-1 $_{1}$ & $\begin{array}{l}-0.520 \\
(-0.91)\end{array}$ & $\begin{array}{l}-0.466 \\
(-0.87)\end{array}$ & $\begin{array}{c}-1.125^{* * *} \\
(-3.62)\end{array}$ & $\begin{array}{c}-0.978^{* * *} \\
(-3.17)\end{array}$ \\
\hline dspread $_{t-1}$ & $\begin{array}{l}-1.235 \\
(-1.26)\end{array}$ & $\begin{array}{l}0.365 \\
(0.34)\end{array}$ & $\begin{array}{l}-1.524 * \\
(-1.77)\end{array}$ & $\begin{array}{l}-0.062 \\
(-0.07)\end{array}$ \\
\hline tspread $_{t-1}$ & $\begin{array}{l}-1.638^{* *} \\
(-2.07)\end{array}$ & $\begin{array}{l}-1.383 * \\
(-1.80)\end{array}$ & $\begin{array}{c}-2.076^{* * *} \\
(-3.49)\end{array}$ & $\begin{array}{c}-1.750 * * * \\
(-2.95)\end{array}$ \\
\hline epratio $_{t-1}$ & $\begin{array}{c}-4.022 * * * \\
(-4.52)\end{array}$ & $\begin{array}{c}-2.771^{* * *} \\
(-2.79)\end{array}$ & $\begin{array}{c}-3.466^{* * *} \\
(-4.28)\end{array}$ & $\begin{array}{c}-2.382 * * * \\
(-2.77)\end{array}$ \\
\hline pcindprod $_{t-1}$ & & $\begin{array}{c}2.306^{* * *} \\
(4.07)\end{array}$ & & $\begin{array}{c}1.991^{* * *} \\
(3.01)\end{array}$ \\
\hline $\operatorname{Adj} R^{2}$ & 19.93 & 30.76 & 11.20 & 19.27 \\
\hline
\end{tabular}

Notes:This table reports the results on the regressions where we investigate whether politicians' aggregated transactions predict future stock market returns. Results are presented separately for the period preceding the STOCK Act (January 2004 to March 2012) and for the full sample period (January 2004 to December 2014). The main variable of interest is the Person-Based Trading Index (PTI). The starting point for PTI is Equation (2), $P T I_{k, t}=\frac{\sum_{j=0}^{2} \text { AllBuyers }_{k, t-j}-\sum_{j=0}^{2} \text { Allsellers }_{k, t-j}}{\sum_{j=0}^{2} \text { AllBuyers }_{k, t-j}+\sum_{j=0}^{2} \text { Allseller }_{k, t-j}}$, where $k$ is an index for firm $k$, and $j$ is an index for time lag. AllBuyers (AllSellers) equals the total number of traders who bought (sold) shares in the stock of firm $k$ in a given month Equation (3) averages $P T I_{k, t}$ across $\mathrm{K}$ firms in month $t$ and produces the series that are used in the regression analysis: $P T I_{t}=\frac{\sum_{k=1}^{K} P T I_{k, t}}{K}$. market $t_{t}$ is the dependent variable that we calculate as the return on the CRSP valueweighted market index minus 1-month Treasury bill rate in month $t$. market $_{t-j}$ is the $j-$ month lagged excess market returns. Other variables are: the 3-month Treasury bill rate (tb3mate), the default spread calculated as the difference in the yields between the BAA and AAA rated corporate debt (dspread), the term spread calculated as the difference between the 10-year Treasury bond yield and the 3-month Treasury bill rate (tspread), the earnings to price ratio calculated as the log of 12-month moving sum of the earnings of the S\&P 500 firms minus the log of the S\&P 500 price level (epratio), and the rate at which industrial production grows (pcindprod). We report the $\mathrm{t}$-statistics in parenthesis that are robust for heteroskedasticity and autocorrelation and based on three lags. The level of significance at the $1 \%, 5 \%$, and $10 \%$ are demonstrated with ${ }^{* * *}, * *$, and $*$, respectively. 
Table 6. Transactions-based trading index and value-weighted market returns.

\begin{tabular}{|c|c|c|c|c|}
\hline \multirow[b]{2}{*}{ Variables } & \multicolumn{2}{|c|}{ Pre-STOCK Act Period } & \multicolumn{2}{|c|}{ Complete Period } \\
\hline & Model I & Model II & Model I & Model II \\
\hline Intercept & $\begin{array}{l}3.991 \\
(1.35)\end{array}$ & $\begin{array}{l}2.168 \\
(0.71)\end{array}$ & $\begin{array}{c}6.438^{* * *} \\
(3.55)\end{array}$ & $\begin{array}{c}4.388^{* *} \\
(2.30)\end{array}$ \\
\hline$T T I_{t-1}$ & $\begin{array}{c}12.213^{* * *} \\
(2.90)\end{array}$ & $\begin{array}{l}8.058^{* *} \\
(2.57)\end{array}$ & $\begin{array}{c}6.760^{* *} \\
(2.17)\end{array}$ & $\begin{array}{l}4.145^{*} \\
(1.70)\end{array}$ \\
\hline Market $_{t-1}$ & $\begin{array}{l}0.071 \\
(0.73)\end{array}$ & $\begin{array}{l}0.084 \\
(0.83)\end{array}$ & $\begin{array}{l}0.061 \\
(0.66)\end{array}$ & $\begin{array}{l}0.072 \\
(0.74)\end{array}$ \\
\hline Market $_{t-3}$ & $\begin{array}{l}0.009 \\
(0.08)\end{array}$ & $\begin{array}{l}-0.055 \\
(-0.50)\end{array}$ & $\begin{array}{l}0.017 \\
(0.19)\end{array}$ & $\begin{array}{l}-0.020 \\
(-0.25)\end{array}$ \\
\hline Market $_{t-6}$ & $\begin{array}{l}-0.335^{* *} \\
(-2.39)\end{array}$ & $\begin{array}{l}-0.304^{* *} \\
(-2.47)\end{array}$ & $\begin{array}{l}-0.274^{* *} \\
(-2.29)\end{array}$ & $\begin{array}{c}-0.251^{* *} \\
(-2.28)\end{array}$ \\
\hline Market $_{t-9}$ & $\begin{array}{l}-0.156 \\
(-1.28)\end{array}$ & $\begin{array}{l}-0.219^{* *} \\
(-2.25)\end{array}$ & $\begin{array}{l}-0.109 \\
(-1.14)\end{array}$ & $\begin{array}{l}-0.151 \text { * } \\
(-1.87)\end{array}$ \\
\hline Market $_{t-12}$ & $\begin{array}{l}0.058 \\
(0.65)\end{array}$ & $\begin{array}{l}0.093 \\
(1.21)\end{array}$ & $\begin{array}{l}0.034 \\
(0.43)\end{array}$ & $\begin{array}{l}0.055 \\
(0.74)\end{array}$ \\
\hline Market $_{t-24}$ & $\begin{array}{c}-0.219^{* *} \\
(-2.43)\end{array}$ & $\begin{array}{l}-0.191^{* *} \\
(-2.23)\end{array}$ & $\begin{array}{l}-0.110 \\
(-1.51)\end{array}$ & $\begin{array}{l}-0.084 \\
(-1.20)\end{array}$ \\
\hline tb3mrate t-1 $_{1}$ & $\begin{array}{l}-0.543 \\
(-0.93)\end{array}$ & $\begin{array}{l}-0.494 \\
(-0.91)\end{array}$ & $\begin{array}{c}-1.119 * * * \\
(-3.61)\end{array}$ & $\begin{array}{c}-0.974^{* * *} \\
(-3.16)\end{array}$ \\
\hline dspread $_{t-1}$ & $\begin{array}{l}-1.472 \\
(-1.48)\end{array}$ & $\begin{array}{l}0.207 \\
(0.19)\end{array}$ & $\begin{array}{l}-1.633 * \\
(-1.86)\end{array}$ & $\begin{array}{l}-0.127 \\
(-0.14)\end{array}$ \\
\hline tspread $_{t-1}$ & $\begin{array}{l}-1.644^{* *} \\
(-2.06)\end{array}$ & $\begin{array}{l}-1.392 * \\
(-1.79)\end{array}$ & $\begin{array}{c}-2.067^{* * * *} \\
(-3.50)\end{array}$ & $\begin{array}{c}-1.740^{* * *} \\
(-2.95)\end{array}$ \\
\hline epratio $_{t-1}$ & $\begin{array}{c}-3.856^{* * *} \\
(-4.47)\end{array}$ & $\begin{array}{c}-2.639 * * * \\
(-2.68)\end{array}$ & $\begin{array}{c}-3.397^{* * * *} \\
(-4.28)\end{array}$ & $\begin{array}{c}-2.330 * * * \\
(-2.73)\end{array}$ \\
\hline pcindprod $_{t-1}$ & & $\begin{array}{c}2.314^{* * *} \\
(4.14)\end{array}$ & & $\begin{array}{c}1.993^{* * *} \\
(3.04)\end{array}$ \\
\hline $\operatorname{Adj} R^{2}$ & 19.60 & 30.49 & 11.13 & 19.20 \\
\hline
\end{tabular}

This table reports the results on the regressions where we investigate whether politicians' aggregated transactions predict future stock market returns. Results are presented separately for the period preceding the STOCK Act (January 2004 to March 2012) and for the full sample period (January 2004 to December 2014). The main variable of interest is the Transactions-Based Trading Index (TTI). The starting point for TTI is Equation (5),

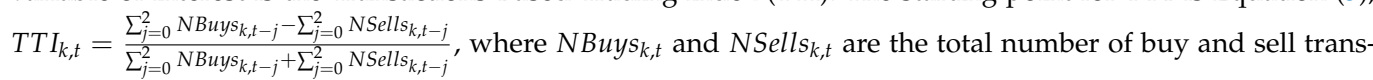
actions in firm $k^{\prime}$ s stock by politicians in month $t$. Equation (6) averages $T T I_{k, t}$ across $\mathrm{K}$ firms in month $t$ and produces the series that are used in the regression analysis: $T T I_{t}=\frac{\sum_{k=1}^{K} T T I_{k, t}}{K}$. market $_{t}$ is the dependent variable that we calculate as the return on the CRSP value-weighted market index minus 1-month Treasury bill rate in month $t$. market $t_{t-j}$ is the $j-$ month lagged excess market returns. Other variables are: the 3-month Treasury bill rate (tb3mate), the default spread calculated as the difference in the yields between the BAA and AAA rated corporate debt (dspread), the term spread calculated as the difference between the 10-year Treasury bond yield and the 3-month Treasury bill rate (tspread), the earnings to price ratio calculated as the log of 12 -month moving sum of the earnings of the S\&P 500 firms minus the log of the S\&P 500 price level (epratio), and the rate at which industrial production grows (pcindprod). We report the t-statistics in parenthesis that are robust for heteroskedasticity and autocorrelation and based on three lags. The level of significance at the $1 \%, 5 \%$, and $10 \%$ are demonstrated with ${ }^{* * *}, * *$, and *, respectively. 
Table 7. Volume-based trading index and value-weighted market returns.

\begin{tabular}{|c|c|c|c|c|}
\hline \multirow[b]{2}{*}{ Variables } & \multicolumn{2}{|c|}{ Pre-STOCK Act Period } & \multicolumn{2}{|c|}{ Complete Period } \\
\hline & Model I & Model II & Model I & Model II \\
\hline Intercept & $\begin{array}{l}3.053 \\
(1.02)\end{array}$ & $\begin{array}{l}1.434 \\
(0.46)\end{array}$ & $\begin{array}{c}5.965^{* * *} \\
(3.26)\end{array}$ & $\begin{array}{c}3.807^{* *} \\
(1.98)\end{array}$ \\
\hline$V T I_{t-1}$ & $\begin{array}{c}13.563^{* * *} \\
(3.21)\end{array}$ & $\begin{array}{c}9.473 * * * \\
(2.71)\end{array}$ & $\begin{array}{c}7.562 * * \\
(2.37)\end{array}$ & $\begin{array}{c}5.008 * \\
(1.92)\end{array}$ \\
\hline Market $_{t-1}$ & $\begin{array}{l}0.063 \\
(0.63)\end{array}$ & $\begin{array}{l}0.077 \\
(0.74)\end{array}$ & $\begin{array}{l}0.067 \\
(0.71)\end{array}$ & $\begin{array}{l}0.082 \\
(0.82)\end{array}$ \\
\hline Market $_{t-3}$ & $\begin{array}{l}0.005 \\
(0.04)\end{array}$ & $\begin{array}{l}-0.058 \\
(-0.53)\end{array}$ & $\begin{array}{l}0.010 \\
(0.11)\end{array}$ & $\begin{array}{l}-0.029 \\
(-0.37)\end{array}$ \\
\hline Market $_{t-6}$ & $\begin{array}{c}-0.327^{* *} \\
(-2.37)\end{array}$ & $\begin{array}{c}-0.299 * * \\
(-2.46)\end{array}$ & $\begin{array}{c}-0.280^{* *} \\
(-2.36)\end{array}$ & $\begin{array}{c}-0.260 * * \\
(-2.40)\end{array}$ \\
\hline Market $_{t-9}$ & $\begin{array}{l}-0.155 \\
(-1.26)\end{array}$ & $\begin{array}{c}-0.217^{* *} \\
(-2.22)\end{array}$ & $\begin{array}{l}-0.110 \\
(-1.16)\end{array}$ & $\begin{array}{c}-0.155^{*} \\
(-1.93)\end{array}$ \\
\hline Market $_{t-12}$ & $\begin{array}{l}0.059 \\
(0.66)\end{array}$ & $\begin{array}{l}0.092 \\
(1.22)\end{array}$ & $\begin{array}{l}0.020 \\
(0.25)\end{array}$ & $\begin{array}{l}0.037 \\
(0.51)\end{array}$ \\
\hline Market $_{t-24}$ & $\begin{array}{c}-0.223^{* *} \\
(-2.55)\end{array}$ & $\begin{array}{c}-0.196^{* *} \\
(-2.32)\end{array}$ & $\begin{array}{l}-0.110 \\
(-1.53)\end{array}$ & $\begin{array}{l}-0.084 \\
(-1.21)\end{array}$ \\
\hline tb3mrate t-1 $_{1}$ & $\begin{array}{l}-0.473 \\
(-0.85)\end{array}$ & $\begin{array}{l}-0.418 \\
(-0.78)\end{array}$ & $\begin{array}{c}-1.058^{* * *} \\
(-3.30)\end{array}$ & $\begin{array}{c}-0.867^{* * *} \\
(-2.80)\end{array}$ \\
\hline dspread $_{t-1}$ & $\begin{array}{l}-1.133 \\
(-1.16)\end{array}$ & $\begin{array}{l}0.420 \\
(0.39)\end{array}$ & $\begin{array}{l}-1.533^{*} \\
(-1.81)\end{array}$ & $\begin{array}{l}-0.041 \\
(-0.05)\end{array}$ \\
\hline tspread $_{t-1}$ & $\begin{array}{c}-1.634^{* *} \\
(-2.15)\end{array}$ & $\begin{array}{l}-1.375 * \\
(-1.83)\end{array}$ & $\begin{array}{c}-1.994 * * * \\
(-3.38)\end{array}$ & $\begin{array}{c}-1.596^{* * *} \\
(-2.76)\end{array}$ \\
\hline epratio $_{t-1}$ & $\begin{array}{c}-4.366^{* * *} \\
(-4.66)\end{array}$ & $\begin{array}{c}-3.053^{* * *} \\
(-2.90)\end{array}$ & $\begin{array}{c}-3.522 * * * \\
(-4.30)\end{array}$ & $\begin{array}{c}-2.308^{* * * *} \\
(-2.62)\end{array}$ \\
\hline pcindprod $_{t-1}$ & $2.269^{* * *}$ & (3.92) & $2.052 * * *$ & $(3.19)$ \\
\hline $\operatorname{Adj} R^{2}$ & 21.02 & 31.46 & 11.93 & 20.56 \\
\hline
\end{tabular}

Notes: This table reports the results on the regressions where we investigate whether politicians' aggregated transactions predict future stock market returns. Results are presented separately for the period preceding the STOCK Act (January 2004 to March 2012) and for the full sample period (January 2004 to December 2014). The main variable of interest is the Volume-Based Trading Index (VTI). The starting point for VTI is Equation (7), $V T I_{k, t}=\frac{\sum_{j=0}^{2} D B u y s_{k, t-j}-\sum_{j=0}^{2} D \text { Sell }_{k_{k, t-j}}}{\sum_{j=0}^{2} D B u y s_{k, t-j}+\sum_{j=0}^{2} D \text { ell }_{k, t-j}}$, where DBuys $k_{k, t}$ and DSells $s_{k, t}$ are the total dollar value of buy and sell transactions in firm $k^{\prime}$ s stock in month $t$ in the sample period. Equation (8) averages $V T I_{k, t}$ across $\mathrm{K}$ firms in month $t$ and produces the series that are used in the regression analysis: $V T I_{t}=\frac{\sum_{k=1}^{K} V T I_{k, t}}{K}$. market $_{t}$ is the dependent variable that we calculate as the return on the CRSP value-weighted market index minus 1-month Treasury bill rate in month $t$. market $t_{t-j}$ is the $j$ - month lagged excess market returns. Other variables are: the 3-month Treasury bill rate (tb3mate), the default spread calculated as the difference in the yields between the BAA and AAA rated corporate debt (dspread), the term spread calculated as the difference between the 10-year Treasury bond yield and the 3-month Treasury bill rate (tspread), the earnings to price ratio calculated as the log of 12-month moving sum of the earnings of the S\&P 500 firms minus the log of the S\&P 500 price level (epratio), and the rate at which industrial production grows (pcindprod). We report the t-statistics in parenthesis that are robust for heteroskedasticity and autocorrelation and based on three lags. The level of significance at the $1 \%, 5 \%$, and $10 \%$ are demonstrated with $* * * * *$, and *, respectively.

When we re-estimated our regression equations with value-weighted excess market returns and $T T I_{t-1}$, we observe the following. For the Pre-STOCK Act period, the coefficient on $\mathrm{TTI}_{t-1}$ was statistically significant at the $1 \%$ level and at the $5 \%$ level under Model I and Model II, respectively. Furthermore, one standard deviation increase in $T T I_{t-1}$ was

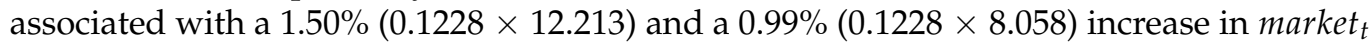
under Model I and Model II, respectively. For the complete period, the corresponding levels of statistical significance were $5 \%$ and $10 \%$. Furthermore, for every one standard deviation increase in $T T I_{t-1}$, we observed a $0.81 \%(0.1193 \times 6.760)$ and a $0.49 \%(0.1193 \times 4.145)$ increase in market $_{t}$ under Model I and Model II, respectively.

We now discuss the results based on value-weighted excess market returns and $V T I_{t-1}$. For the Pre-STOCK Act period, the coefficient on $V T I_{t-1}$ was statistically significant at the $1 \%$ regardless of the model, and for one standard deviation change in $V T I_{t-1}$, we 
observed a $1.68 \%(0.1236 \times 13.563)$ and a $1.17 \%(0.1236 \times 9.473)$ change in the excess market returns under Model I and Model II, respectively. For the complete period, the coefficient of $V T I_{t-1}$ is significant at the $5 \%$ level under Model I and at the $10 \%$ level under Model II. Furthermore, and one standard deviation increase in $V T I_{t-1}$ was associated with a $0.92 \%(0.1210 \times 7.562)$ and a $0.61 \%(0.1210 \times 5.008)$ increase in the excess market returns.

Compared to the results under equal-weighted excess market returns, we observed the same or slightly better levels of statistical significance and lower magnitudes of economic significance under the value-weighted excess market returns. Furthermore, in most cases, the fit of the models (as measured by adjusted $R^{2}$ ) was better under the equal-weighted excess market returns. These results collectively imply that politicians had a slightly better informational advantage when it came to small stocks. However, their informational advantage extended to large stocks as well. It is important to note that we are chiefly concerned with the macroeconomic (i.e., economy-wide) information content of politicians' trades rather than firm-specific information contained in politicians' trades. In the light of this distinction, the results in this section suggest that politicians traded small and large stocks based on comparable levels of non-public macroeconomic information.

\subsection{Outliers}

Are our results driven by outliers? To address this concern, we winsorized all the variables used in the regression analysis at the 5th and the 95th percentile levels and re-estimate Models I and II in Table 2 through Table 7. In untabulated results, we observed the following. The statistical significance for the coefficients of our key variables of interest $\left(P T I_{t-1}, T T I_{t-1}\right.$, and $\left.V T I_{t-1}\right)$ improved or stayed the same across all the models and all the periods. The magnitude of the coefficients on our key variables of interest improved in all but one cases across all the models and all the periods. These results suggest that the potential presence of outliers may actually have been causing a downward bias in our estimations, and the original results reported in Table 2 through Table 7 represent conservative estimates for the coefficients on $P T I_{t-1}, T T I_{t-1}$, and $V T I_{t-1}$.

\section{Conclusions}

Our study directly contributes to the literature on stock trading by members of Congress. Using 76,182 stock transactions done by members of Congress, we document that politicians' aggregated transactions predict future stock market returns in the Pre-STOCK Act period (January 2004 to March 2012). Hence, we extend the analysis done by Karadas et al. (forthcoming) who find that politicians' aggregated stock trades predict the stock market returns over the 2004-2010 period. The results reported by Karadas et al. (forthcoming) fall in between our Pre-STOCK Act period results and complete period results in terms of their economic significance. ${ }^{7}$ This suggests that the stock trades made by politicians over about two years preceding the STOCK Act still contain important information.

Furthermore, extending the sample until the end of 2014 (using 101,191 transactions) leads to a diminished predictive ability for politicians' aggregated transactions. This implies that that members of Congress used non-public macroeconomic information in their stock trades prior to the STOCK Act, and STOCK Act was influential in affecting politicians' tendency to use non-public macroeconomic information in their stock trades. Hence, our paper adds to the literature on the effect of STOCK Act on politicians' trading outcomes (e.g., Karadas 2019; Belmont et al. 2020), but differs from those studies by its focus on non-public macroeconomic information content of politicians' stock transactions. Moreover, we find politicians enjoy a small informational advantage in small stocks in a similar fashion to corporate insiders (Lakonishok and Lee 2001). The results for our analysis provide a helpful input in the current debate on the need to further restrict politicians' stock trades under the STOCK Act 2.0 initiative.

Author Contributions: Conceptualization, S.K. and M.T.T.S.; methodology, S.K. and M.T.T.S.; software, S.K.; formal analysis, S.K., M.T.T.S. and J.H.; data curation, S.K.; writing-original draft 
preparation, S.K. and M.T.T.S.; writing — review and editing, J.H. All authors have read and agreed to the published version of the manuscript.

Funding: This research received no external funding, with the exception of article processing charges, which are covered by the Center for Free Enterprise at West Virginia University.

Data Availability Statement: Data on politician trades are available from the Center for Responsive Politics in a bulk download at https:/ / www.opensecrets.org/bulk-data accessed on 9 June 2017. Terms of the stock data obtained from the Center for Research in Security Prices do not allow sharing in public repositories.

Conflicts of Interest: Karadas and Schlosky report no conflict of interests. Joshua Hall has received funding during their career from the Charles Koch Foundation, the Thomas Smith Foundation, the Alliance for Markets Solutions, the Institute for Humane Studies, Liberty Fund, and honoraria from over 30 colleges and universities. These relationships had no role in the design of the study; in the collection, analyses, or interpretation of data; in the writing of the manuscript, or in the decision to publish the results.

\section{Notes}

1 Representative Collins was a board member and large shareholder in the company and he did not sell his stocks. However, his son, his son's father-in-law, and six other individuals sold their shares before the news became public, collectively avoiding losses more than \$768,000 (US Department of Justice 2019).

2 The Clerk of the House has been publishing the financial disclosure reports of its members online since 2008 as a requirement under the Honest Leadership and Open Government Act of 2007 (Section 304). Nevertheless, the information content of these publications is very shallow because they only report the filing dates of the disclosure reports, but not their contents. Therefore, this act is not comparable to the STOCK Act in its scope.

3 It is important to note that the insider trading case involving Representative Collins is not novel in a sense that someone with private information passes that information to others. Nocera (2020) argues that the existing laws on insider trading that predate the Stop Trading on Congressional Knowledge (STOCK) Act of 2012 would have been sufficient to prosecute Representative Collins.

4 We thank Professor Welch Goyal, Professor Robert Shiller, and St. Louis Fed for providing the data and construction methodology for these control variables.

$5 \quad$ For further details on return predictability as well as the effect of government policies on the economic output, please see Balvers et al. (1990); De Long et al. (1988); Hong et al. (2007).

6 To be brief, we only report the descriptive statistics for the Pre-STOCK Act period. The descriptive statistics for the complete period are available from the authors upon request.

7 The coefficients reported by Karadas et al. (forthcoming) on the measure of politicians' aggregated trades (PTI $\left.I_{t-1}\right)$ are larger in magnitude than those we find for the Pre-STOCK Act period. However, when we make a comparison on the basis of economic significance (coefficient $\times$ standard deviation), we observe better economic significance for the Pre-STOCK Act period.

\section{References}

Augustin, Patrick, Francis Cong, and Marti Subrahmanyam. 2020. Insider trading by Congress? It's time to fix the law. The Hill, April 19.

Balvers, Ronald J., Thomas F. Cosimano, and Bill McDonald. 1990. Predicting stock returns in an efficient market. The Journal of Finance 45: 1109-28. [CrossRef]

Belmont, William, Bruce Sacerdote, Ranjan Sehgal, and Ian Van Hoek. 2020. Relief Rally: Senators As Feckless As the Rest of Us at Stock Picking. Working Paper. Cambridge: National Bureau of Economic Research.

De Long, J. Bradford, Lawrence H. Summers, N. Gregory Mankiw, and Christina D. Romer. 1988. How does macroeconomic policy affect output? Brookings Papers on Economic Activity 1988: 433-94. [CrossRef]

Diemer, Miriam. 2014. Most Senators File Financial Disclosures Electronically-Sort Of. Washington, DC: Center for Responsive Politics.

Eggers, Andrew C., and Jens Hainmueller. 2014. Political capital: Corporate connections and stock investments in the US Congress, 2004-2008. Quarterly Journal of Political Science 9: 169-202. [CrossRef]

Faturechi, Robert, and Derek Willis. 2020. Senator dumped up to $\$ 1.7$ million of stock after reassuring public about coronavirus preparedness. ProPublica, March 19.

Hall, Joshua C., Serkan Karadas, and Minh Tam Tammy Schlosky. 2017. Abnormal returns from joining Congress? Evidence from new members. Journal of Financial Economic Policy 9: 450-74. [CrossRef] 
Hong, Harrison, Walter Torous, and Rossen Valkanov. 2007. Do industries lead stock markets? Journal of Financial Economics 83: 367-96. [CrossRef]

Howe, John S., Emre Unlu, and Xuemin Yan. 2009. The predictive content of aggregate analyst recommendations. Journal of Accounting Research 47: 799-821. [CrossRef]

Jiang, Xiaoquan, and Mir A. Zaman. 2010. Aggregate insider trading: Contrarian beliefs or superior information? Journal of Banking $\mathcal{E}$ Finance 34: 1225-36.

Karadas, Serkan. 2018. Family ties and informed trading: Evidence from Capitol Hill. Journal of Economics and Finance 42: 211-48. [CrossRef]

Karadas, Serkan. 2019. Trading on private information: Evidence from members of Congress. Financial Review 54: 85-131. [CrossRef]

Karadas, Serkan, and Jorida Papakroni. 2019. Local predictive ability of analyst recommendations. Review of Financial Economics 37: 351-71. [CrossRef]

Karadas, Serkan, Minh Tam Tammy Schlosky, and Joshua C. Hall. forthcoming. Aggregrate Congressional trading and stock market returns. Journal of Financial Economic Policy.

Khuzami, R. 2011. Statement to the House Committee on Financial Services. 6 December: Testimony on The Stop Trading on Congressional Knowledge Act Testimony. Washington, DC: Government Printing Office.

Kindy, K., S. Higham, D. S. Fallis, and D. Keating. 2012. Lawmakers reworked financial portfolios after talks with Fed, Treasury officials. Washington Post, June 24.

Kroft, Steve. 2011. Congress: Trading stock on inside information. 60 Minutes, November 13.

Lakonishok, Josef, and Inmoo Lee. 2001. Are insider trades informative? Review of Financial Studies 14: 79-111. [CrossRef]

Markay, L., W. Bredderman, and S. Brodey. 2020. Sen. Kelly Loeffler dumped millions in stock after coronavirus briefing. Daily Beast, March 20.

Merle, R. 2020. Ex-congressman Chris Collins sentenced to 2 years on insider-trading, false-statement charges. Washington Post, January 17.

Mullins, Brody. 2015. Sen. Bob Corker Failed to Properly Disclose Millions of Dollars in Income. The Wall Street Journal, December 13.

Nagy, D. M. 2011. Statement to the House Committee on Financial Services. 6 December: Testimony on The Stop Trading on Congressional Knowledge Act Testimony. Washington, DC: Government Printing Office.

Nocera, Joe. 2020. "Stop Trading" Act for Congress isn't stopping much trading. Bloomberg, December 4.

Schweizer, Peter. 2011. Throw Them All Out: How Politicians and Their Friends Get Rich Off Insider Stock Tips, Land Deals, And Cronyism That Would Send The Rest Of Us To Prison. Boston: Houghton Mifflin Harcourt.

Severns, M., and K. O'Donnell. 2020. House members, Senate aides traded stocks in early days of coronavirus. Politico, March 21.

Seyhun, H. Nejat. 1988. The information content of aggregate insider trading. Journal of Business 61: 1-24. [CrossRef]

Slaughter, L. 2011. Statement to the House Committee on Financial Services. 6 December: Testimony on The Stop Trading on Congressional Knowledge Act Testimony. Washington, DC: Government Printing Office.

Slodysko, Brian. 2021. As Pandemic Spread Pain and Panic, Congressman Chased Profit. Washington, DC: Associated Press.

US Congress. 2012. Stop Trading on Congressional Knowledge (Stock) Act of 2012. Available online: https://www.gpo.gov/fdsys/ pkg/PLAW-112publ105/html/PLAW-112publ105.htm (accessed on 4 June 2021).

US Congress. 2020. To Require Senior Officials to Report Payments Received from the Federal Government and to Improve the Filing and Disclosure of Financial Disclosures by Members of Congress, Congressional Staff, and Very Senior Employees. Available online: https: / /www.congress.gov/bill/116th-congress/house-bill/8362?s=1\&r=37 (accessed on 5 June 2021).

US Department of Justice. 2019. Christopher Collins Pleads Guilty to Insider Trading Scheme and Lying to Federal Law Enforcement Agents. Washington, DC: US Department of Justice.

Vardi, Nathan. 2013. Did Obama and Congress use national security fears to gut the Stock Act? Forbes, April 21.

Ziobrowski, A. J. 2009. Statement to the Subcommittee on Oversight and Investigations off the Committee on Financial Services. 13 July: Testimony on Preventing Unfair Trading by Government Officials. Washington, DC: Government Printing Office.

Ziobrowski, Alan J., James W. Boyd, Ping Cheng, and Brigitte J. Ziobrowski. 2011. Abnormal returns from the common stock investments of members of the US House of Representatives. Business and Politics 13: 1-22. [CrossRef]

Ziobrowski, Alan J., Ping Cheng, James W. Boyd, and Brigitte J. Ziobrowski. 2004. Abnormal returns from the common stock investments of the us senate. Journal of Financial and Quantitative Analysis 39: 661-76. [CrossRef] 